\title{
Effects of Mo on the Passive Films Formed on Ni-(15, 30)Cr-5Mo Alloys in $\mathrm{pH} 8.5$ Buffer Solution
}

\author{
HeeJin Jang* and HyukSang Kwon ${ }^{\dagger}$ \\ Dept. of Metallurgical Engineering, Chosun University, 375 Seosuk-dong, Dong-gu, Gwangju, 501-759, Republic of \\ Korea \\ ${ }^{\dagger}$ Dept. of Materials Science and Engineering, Korea Advanced Institute of Science and Technology, 373-1 Guseong- \\ dong, Yuseong-gu, Daejeon, 305-701, Republic of Korea
}

(Received July 22, 2009 : Accepted Jyly 30, 2009)

\begin{abstract}
The composition and semiconducting properties of the passive films formed on $\mathrm{Ni}$ $(15,30) \mathrm{Cr}-5 \mathrm{Mo}$ alloys in $\mathrm{pH} 8.5$ buffer solution were examined. The depth concentration profile of passive films formed on $\mathrm{Ni}-(15,30) \mathrm{Cr}-5 \mathrm{Mo}$ in $\mathrm{pH} 8.5$ buffer solution showed that Mo enhances the enrichment of $\mathrm{Cr}$. The Mott-Schottky plot for the passive film on Ni-(15, 30)Cr$5 \mathrm{Mo}$ closely resembled that for the film on $\mathrm{Cr}$, whereas those for the less Cr-enriched film on Mo-free alloys showed similar behavior to that for the film on Ni. The acceptor density was reduced by increasing $\mathrm{Cr}$ content in $\mathrm{Ni}-(15,30) \mathrm{Cr}-(0,5) \mathrm{Mo}$ alloys, but addition of Mo considerably increased the acceptor density.
\end{abstract}

Keywords : Ni-Cr-Mo alloy, Passive film, Mott-Schottky analysis

\section{Introduction}

Ni-Cr-Mo alloy such as C22 (Ni-22Cr-13Mo-3Fe-3W) is one of the most corrosion resistant of the Ni-based alloys. ${ }^{1,2)}$ The $\mathrm{C} 22$ alloy is the candidate material for the container of high level nuclear waste packages in the Yucca Mountain repository (Nevada, USA) requiring long-term durability up to about 10,000 years. ${ }^{3-5)}$ The corrosion resistance of $\mathrm{Ni}-\mathrm{Cr}-\mathrm{Mo}$ alloys is largely dependent on the content of $\mathrm{Cr}$ and Mo ${ }^{6-7)} \mathrm{Cr}$ alloyed in Ni-based alloys is known to play a major role in enforcing passivity, significantly lowering both anodic dissolution rate and passive current density. ${ }^{8-11)}$ However, on the other side, $\mathrm{Cr}$ may cause increased corrosion susceptibility in highly oxidizing environments through transpassive dissolution. $^{10-11)}$ Mo alloyed in $\mathrm{Ni}-\mathrm{Cr}$ alloys enhances corrosion resistance of alloys by increasing corrosion potential and reduces anodic dissolution rate, passive current density and corrosion rate in acidic media, $9,12,13$ ) but it accelerates transpassive dissolution of $\mathrm{Cr}^{14)}$

*E-mail: heejin@chosun.ac.kr
Mo is also noted for beneficial effect on localized corrosion resistance of $\mathrm{Ni}$-based alloys and stainless steels. $^{13,15,16)}$

According to Lloyd et al., ${ }^{12,17)}$ the passive films formed on high-Cr alloys such as Alloy 625, C22, and $\mathrm{C} 2000$ in $1 \mathrm{M} \mathrm{NaCl}+\mathrm{H}_{2} \mathrm{SO}_{4}$ solution have duplex layered structure composed of inner $\mathrm{Cr}-\mathrm{Ni}$ rich oxide layer and outer Cr-Mo rich oxide layer. On the contrary, he reported that the passive films of Alloy $\mathrm{C} 4$ and C276 with low Cr content (about 16wt.\%) did not show such a clear separation of layers from XPS and TOF SIMS analyses. Huang ${ }^{18)}$ reported that the passive films formed on $\mathrm{Ni}-(12.4 \sim 21.7) \mathrm{Cr}-(4.9 \sim 8.4) \mathrm{Mo}$ alloys in artificial saliva $\left(\mathrm{pH} 5,37^{\circ} \mathrm{C}\right)$ comprise $\mathrm{Ni}(\mathrm{OH})_{2}$, $\mathrm{NiO}$, and $\mathrm{Cr}_{2} \mathrm{O}_{3}$, and $\mathrm{MoO}_{3}$.

Corrosion resistance of an alloy is dependent on the nature of its passive film, so many research have been done to reveal the structure, composition, and the semiconducting properties of the passive film. In spite of the importance of Mo in improving corrosion resistance of Ni-Cr-Mo alloys, the influences of Mo on the semiconducting properties of the passive films of Ni-Cr-Mo alloys have not yet been clarified. In this work, the research objective is to examine the semi- 
conducting properties of the passive films formed on Ni- $(15,30) \mathrm{Cr}-5 \mathrm{Mo}$ alloys in $\mathrm{pH} 8.5$ buffer solution with focus on the effects of Mo on the passivity of the alloys using photoelectrochemical technique and Mott-Schottky analysis.

\section{Experimental Procedures}

High purity Ni-(15, 30)Cr-5Mo alloys were used as the working electrodes. The alloys were prepared by a vacuum-arc-melting, and then casts in a form of button. The cast was homogenized for $100 \mathrm{~min}$ at $1200^{\circ} \mathrm{C}$, and then hot rolled into $3 \mathrm{~mm}$ thick plate. Specimens were prepared by cold rolling the hot rolled plates into $1.5 \mathrm{~mm}$ thick sheets and solution annealing at $1050^{\circ} \mathrm{C}$ for $20 \mathrm{~min}$, followed by water quenching. The working electrode was mounted in an epoxy resin with an exposed area of $0.2 \mathrm{~cm}^{2}$.

A conventional three-electrode cell of 1 L-multi neck flask was used electrochemical measurements. The cell was equipped with a platinum counter electrode and a saturated calomel reference electrode (SCE). All the electrode potentials are referred to the SCE. The experiments were carried out in deaerated $\mathrm{pH} 8.5$ buffer solution, made of $\mathrm{H}_{3} \mathrm{BO}_{3}, \mathrm{C}_{6} \mathrm{H}_{8} \mathrm{O}_{7} \cdot \mathrm{H}_{2} \mathrm{O}$, and $\mathrm{Na}_{3} \mathrm{PO}_{4} \cdot 12 \mathrm{H}_{2} \mathrm{O}$.

The working electrode was cathodically cleaned by polarization to $-1.5 \mathrm{~V}_{\mathrm{SCE}}$ for $5 \mathrm{~min}$, and then passive film was formed on the alloy by stepping applied potential to a film formation potential $\left(U_{f}\right)$ to which the alloy was polarized for more than $24 \mathrm{~h}$ before a steady state current density had been achieved. Then the composition of the passive film was examined by XPS. PHI 5800 ESCA System with Al K $\alpha$ anode $(250 \mathrm{~W}, 10 \mathrm{kV})$ was used for XPS analysis. The reference energies were the $\mathrm{C} 1 \mathrm{~s}$ signal at $284.6 \mathrm{eV}$. Indepth composition profiling of passive film was performed using Ar ion gun (base pressure $=2 \times 10^{-10}$ torr, working pressure $=2 \times 10^{-8}$ torr, energy: $3 \sim 4 \mathrm{kV}$ ). The sputter rate was calibrated with $\mathrm{SiO}_{2}$. For MottSchottky analysis, the specimen was passivated at an $U_{f}$ for $2 \mathrm{~h}$ prior to measuring capacitance with sweeping the applied potential at a rate of $-1 \mathrm{mV} / \mathrm{s}$. The excitation voltage was $10 \mathrm{mV}$ (peak-to-peak) and the frequency was $1 \mathrm{kHz}$.

\section{Results and Discussion}

Fig. 1 shows the potentiodynamic polarization re-

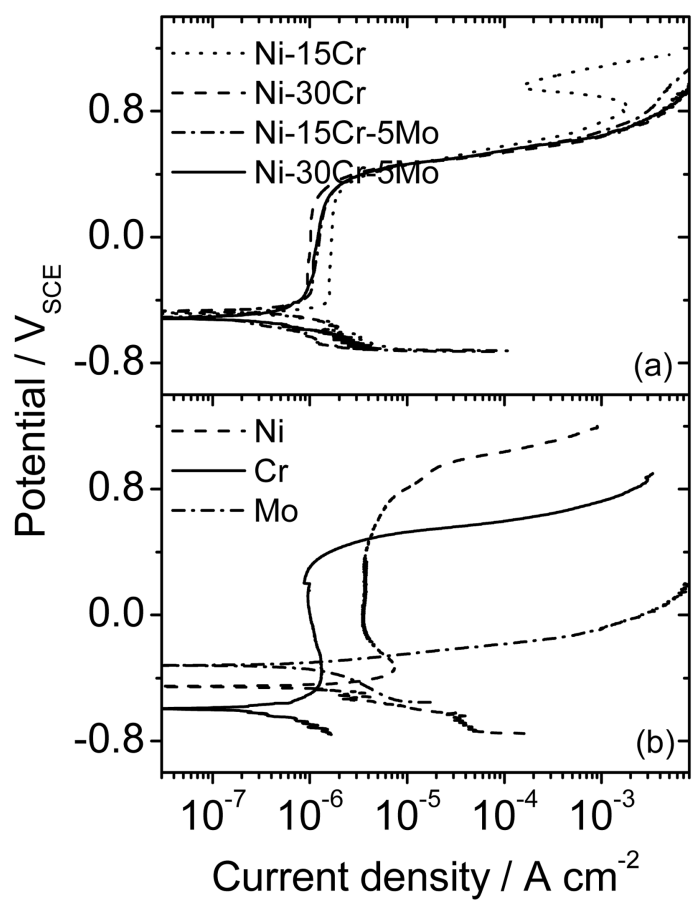

Fig. 1. Potentiodynamic polarization curves for (a) Ni$(15,30) \mathrm{Cr}-(0,5) \mathrm{Mo},(\mathrm{b}) \mathrm{Ni}, \mathrm{Cr}$, and $\mathrm{Mo}$ in deaerated $\mathrm{pH}$ 8.5 buffer solution at ambient temperature. Potential scan rate was $0.5 \mathrm{mV} / \mathrm{s}$.

sponses of $\mathrm{Ni}-(15,30) \mathrm{Cr}-(0,5) \mathrm{Mo}, \mathrm{Ni}, \mathrm{Cr}$, and $\mathrm{Mo}$ in $\mathrm{pH} 8.5$ buffer solution. The corrosion potential of Ni-(15, 30)Cr-5Mo was $-0.5 \mathrm{~V}_{\text {SCE }}$ (Fig. 1(a)), being slightly higher than $\mathrm{Cr}$ and lower than those of $\mathrm{Ni}$ and Mo (Fig. 1(b)). The passive region extended up to $0.3 \mathrm{~V}_{\mathrm{SCE}}$ at which transpassive dissolution of $\mathrm{Cr}$ begins, demonstrating that the passivity of $\mathrm{Ni}-(15$, 30)Cr-5Mo is governed largely by Cr. Secondary passivation did not occurred as known that Mo promotes the transpassive dissolution of Ni-based alloys. ${ }^{7,11)}$ The polarization curves of $\mathrm{Ni}-(15,30) \mathrm{Cr}$ $5 \mathrm{Mo}$ were practically overlapping. The passive current density of $\mathrm{Ni}-15 \mathrm{Cr}$ was decreased by addition Mo (Fig. 1(a)), but that of Ni-30Cr was a little increased at high potentials by alloying with Mo (Fig. 1(b)).

Fig. 2 shows the concentration profiles of $\mathrm{Ni}, \mathrm{Cr}$, and $\mathrm{Mo}$ in the passive film formed on $\mathrm{Ni}-(15,30)$ Cr-5Mo alloys at $-0.1 \mathrm{~V}_{\mathrm{SCE}}$ in $\mathrm{pH} 8.5$ buffer solution. The thickness of passive film was estimated to be about $3.0 \mathrm{~nm}$, being slightly higher for the alloy with higher $\mathrm{Cr}$. The chemical composition of the passive film on $\mathrm{Ni}-15 \mathrm{Cr}-5 \mathrm{Mo}$ was dominated by $\mathrm{Ni}$ oxide. 


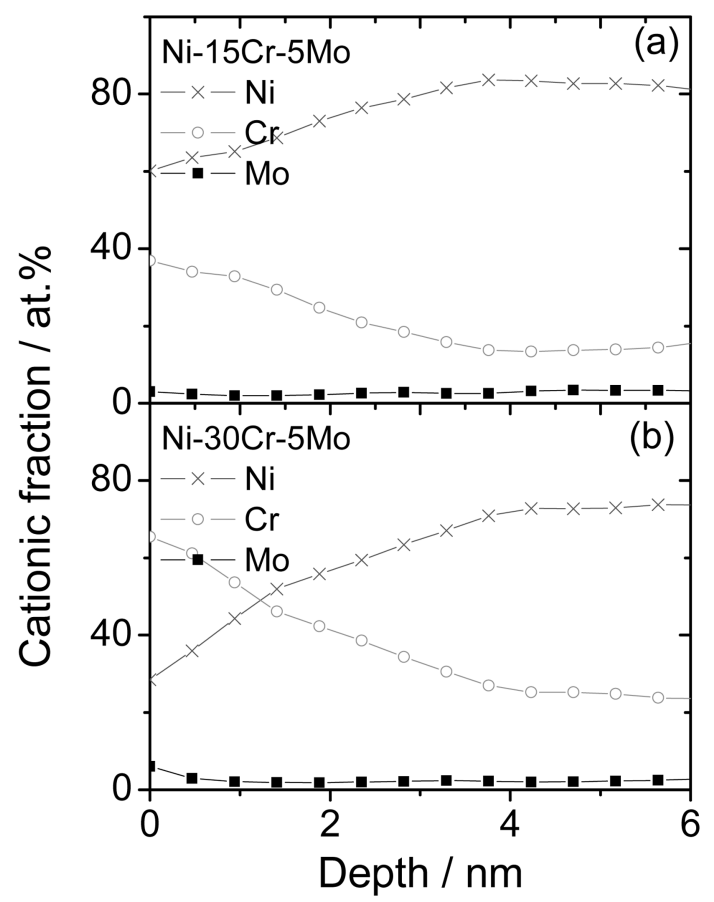

Fig. 2. XPS depth concentration profiles of $\mathrm{Ni}, \mathrm{Cr}$, and Mo for the passive film formed on (a) Ni-15Cr-5Mo and (b) Ni-30Cr-5Mo alloys at $-0.1 \mathrm{~V}_{\mathrm{SCE}}$ in $\mathrm{pH} 8.5$ buffer solution at ambient temperature for $24 \mathrm{~h}$.

However, $\mathrm{Cr}$ content in the film was found to be more than twice compared with that in the alloy. The concentration of Mo was almost constant through the film and the alloy. In contrast, the passive film of Ni-30Cr-5Mo was highly Cr-enriched, with Ni significantly depleted at the outer region of the film.

Effects of Mo on the concentration of $\mathrm{Cr}$ are shown in Fig. 3. The concentration of $\mathrm{Cr}$ at the surface of the passive film was increased by addition of Mo in the alloys, especially for the film on the high-Cr alloys. From these results, we expect that Mo enhances the dominance of $\mathrm{Cr}$ on the passivity of the Ni-Cr-Mo alloys, as confirmed by the potentiodynamic polarization responses as already shown in Fig. 1.

The effects of Mo on the Mott-Schottky plots for the passive film on $\mathrm{Ni}-(15,30) \mathrm{Cr}-5 \mathrm{Mo}$ are shown in Fig. 4. The passive film on $\mathrm{Ni}-(15,30) \mathrm{Cr}-5 \mathrm{Mo}$ exhibited much higher capacitance values than Ni$(15,30) \mathrm{Cr}$, and the shape of Mott-Schottky plots closely resembled that for the passive film of $\mathrm{Cr}$. The Mott-Schottky plots for the passive films on Ni$(15,30) \mathrm{Cr}-5 \mathrm{Mo}$ well agree with the potentiody-

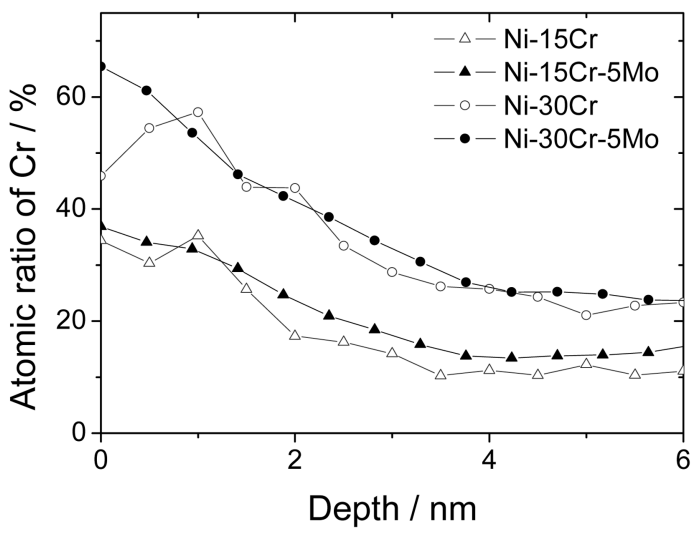

Fig. 3. Effects of Mo on the concentration profile of $\mathrm{Cr}$ in the passive film of $\mathrm{Ni}-(15,30) \mathrm{Cr}-(0,5) \mathrm{Mo}$ alloys.

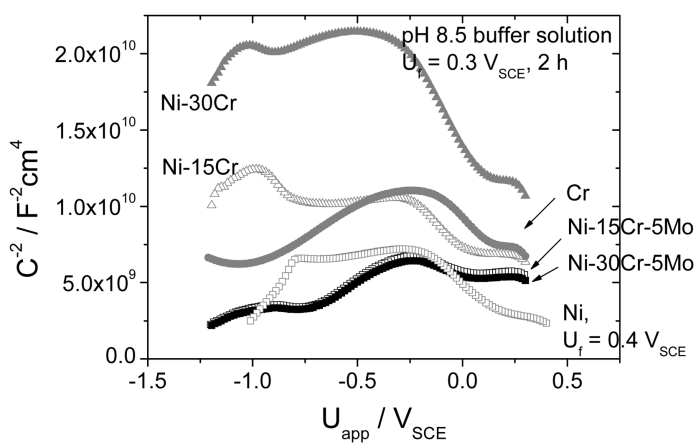

Fig. 4. Mott-Schottky plots for the passive films formed on $\mathrm{Ni}-(15,30) \mathrm{Cr}-5 \mathrm{Mo}$ in $\mathrm{pH} 8.5$ buffer solution.

namic polarization curves (Fig. 1) in that $\mathrm{Cr}$ dominates the electrochemical behavior of $\mathrm{Ni}-(15,30) \mathrm{Cr}-5 \mathrm{Mo}$.

The Mott-Schottky plots showed the linear region with negative slope at $-0.2 \sim 0.1 \mathrm{~V}_{\mathrm{SCE}}$ exhibiting p-type semiconductivity as known for passive film of $\mathrm{Cr}^{19}{ }^{19}$ From the linear regions, flat band potential for the passive films were measured to be $0.7 \mathrm{~V}_{\mathrm{SCE}}$ for $\mathrm{Cr}$, $1.16 \mathrm{~V}_{\mathrm{SCE}}$ for $\mathrm{Ni}-15 \mathrm{Cr}-5 \mathrm{Mo}$, and $1.00 \mathrm{~V}_{\mathrm{SCE}}$ for $\mathrm{Ni}$ $30 \mathrm{Cr}-5 \mathrm{Mo}$. The acceptor density $\left(\mathrm{N}_{\mathrm{A}}\right)$ for the passive films was $8.18 \times 10^{20} \mathrm{~cm}^{-3}$ for $\mathrm{Cr}, 2.26 \times 10^{21} \mathrm{~cm}^{-3}$ for $\mathrm{Ni}-15 \mathrm{Cr}-5 \mathrm{Mo}$, and $2.08 \times 10^{21} \mathrm{~cm}^{-3}$ for Ni-30Cr-5Mo.

In contrast to the cases of $\mathrm{Ni}-(15,30) \mathrm{Cr}$, the Mott-Schottky plots for the passive films on Ni-(15, 30)Cr-5Mo and $\mathrm{Cr}$ shown in Fig. 4 exhibited also ntype semiconductivity, ${ }^{20-22)}$ as confirmed from the linear region with positive slope at $-0.7 \sim-0.3 \mathrm{~V}_{\mathrm{SCE}}$. The flat band potentials estimated from the n-type region were $-1.67 \mathrm{~V}_{\mathrm{SCE}}$ for the passive film of $\mathrm{Cr}$, $-1.1 \mathrm{~V}_{\mathrm{SCE}}$ and $-1.2 \mathrm{~V}_{\mathrm{SCE}}$ for each of the films on 


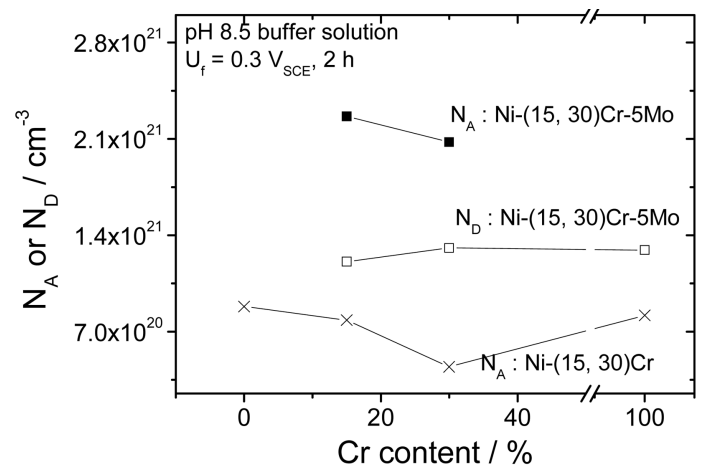

Fig. 5. Effects of contents of $\mathrm{Cr}$ and Mo on $N_{A}$ and $N_{D}$ for the passive film formed on $\mathrm{Ni}-(15,30) \mathrm{Cr}-5 \mathrm{Mo}$ at $0.3 \mathrm{~V}_{\text {SCE }}$ in $\mathrm{pH} 8.5$ buffer solution.

Ni-(15, 30)Cr-5Mo, respectively. The donor density $\left(\mathrm{N}_{\mathrm{D}}\right)$ was $1.29 \times 10^{21}, 1.21 \times 10^{21}$, and $1.31 \times 10^{21} \mathrm{~cm}^{-3}$ for each of the passive films formed on $\mathrm{Cr}$, Ni$15 \mathrm{Cr}-5 \mathrm{Mo}$, and $\mathrm{Ni}-30 \mathrm{Cr}-5 \mathrm{Mo}$, respectively. The densities of acceptor and donor measured from the Mott-Schottky plots for the passive films of Ni-(15, $30) \mathrm{Cr}-5 \mathrm{Mo}$ are summarized in Fig. 5. The acceptor density for the passive film of $\mathrm{Ni}-(15,30) \mathrm{Cr}-5 \mathrm{Mo}$ was about three times higher than that for the film on Mofree alloys, and decreased with increase in $\mathrm{Cr}$ content in the alloy. It implies that high $\mathrm{Cr}$ concentration in the passive film is not the exclusive factor to reduce the defect density but seems to have some effect within an alloy system, i.e., Ni-Cr or Ni-Cr-Mo. The donor density for the passive film on $\mathrm{Ni}-(15,30) \mathrm{Cr}-5 \mathrm{Mo}$ was almost constant with the $\mathrm{Cr}$ content and comparable with that for the film on pure Cr. Improvement of protectiveness of passive film by increasing $\mathrm{Cr}$ content in the alloy can be explained by the reduction of acceptor density, i.e., concentration of cation vacancy, ${ }^{23)}$ in the film. However, beneficial effects of Mo on the corrosion resistance are not supposed to be associated with the concentration of cation vacancy largely increased by addition of Mo, as presented in Fig. 5 . It should be, instead, supported by some other mechanism such as bipolar model of the passive film, ${ }^{24-25)}$ precipitation of molybdate or oxyanion on active sites, ${ }^{26-27)}$ and/or electrostatic interaction of $\mathrm{Mo}^{6+}$ with cation vacancies. ${ }^{28)}$ Nevertheless, it is still required to investigate the defect properties of passive film formed on Ni-Cr-Mo alloys in solution with low $\mathrm{pH}$ and/or chloride ion, in which the effects of Mo on the passivity will be prominently revealed, by extension of this work in $\mathrm{pH} 8.5$ buffer solution.

\section{Conclusions}

The effects of Mo on the passivity of Ni-(15, 30) $\mathrm{Cr}-5 \mathrm{Mo}$ in $\mathrm{pH} 8.5$ buffer solution at ambient temperature were examined by XPS and Mott-Schottky analysis. The potentiodynamic polarization behavior of $\mathrm{Ni}-(15,30) \mathrm{Cr}-5 \mathrm{Mo}$ appeared to be controlled largely by $\mathrm{Cr}$. Mo appeared to slightly promote transpassive dissolution of Ni-Cr alloys. From XPS analysis, addition of Mo enhanced $\mathrm{Cr}$ enrichment at the surface of the passive film. This effect was more appreciable for $\mathrm{Ni}-30 \mathrm{Cr}$ alloys than for $\mathrm{Ni}-15 \mathrm{Cr}$ alloys. Mott-Schottky plots for the passive film on Ni-(15, 30) $\mathrm{Cr}-5 \mathrm{Mo}$ closely resembled that for the film on $\mathrm{Cr}$, exhibiting both n-type and p-type semiconducting properties. The density of acceptor, i.e., cation vacancy, was decreased by increasing $\mathrm{Cr}$ content, but considerably increased by addition of Mo in the alloys. The donor density did not depend on the composition of the alloy.

\section{References}

1. W. Z. Friend, Corrosion of Nickel and Nickel-Base Alloys, Wiley Interscience, New York, 1980, p. 307.

2. N. Sridhar, 'Corrosion of Nickel-Base Alloys', Haynes International Conference Proceedings, 2000, p. 643.

3. G. M. Gordon, 'Corrosion considerations related to permanent disposal of high-level radioactive waste' Corrosion., 58, 811 (2002).

4. J. J. Gray, J. R. Hayes, G. E. Gdowski, B. E. Viani, and C. A. Orme, 'Influence of Solution pH, Anion Concentration, and Temperature on the Corrosion Properties of Alloy 22' J. Electrochem. Soc., 153, B61 (2006).

5. N. Priyantha, P. Jayaweera, D. D. Macdonald, and A. Sun, 'An electrochemical impedance study of Alloy 22 in $\mathrm{NaCl}$ brine at elevated temperature. I. Corrosion behavior' J. Electroanal. Chem., 572, 409 (2004).

6. A. Nadezhdin and D. Wensley, Mater. Perform., 31, 57 (1992).

7. M. Bojinov, G. Fabricius, P. Kinnunen, T. Laitinen, K. Mäkelä, T. Saario, G. Sundholm, and K. Yliniemi, 'Transpassive dissolution of Ni-Cr alloys in sulphate solutionscomparison between a model alloy and two industrial alloys' Electrochim. Acta, 47, 1697 (2002).

8. H. Nanjo, N. J. Laycock, H. Deng, I. Ishikawa, and N. Sanada, 'Atomic-scale flattening of $\mathrm{Ni}-\mathrm{Cr}$ alloy surfaces by electrochemical passivation treatments' Curr. Appl. Phys., 4, 156 (2004).

9. Y. Takizawa, K. Sugahara, 'Corrosion-resistant Ni-Cr-Mo alloys in hot concentrated sulphuric acid with active carbon' 
Mater. Sci. Eng. A, 198, 145 (1995).

10. M. Bojinov, G. Fabricius, P. Kinunnen, T. Laitinen, K. Mäkelä, T. Saario, and G. Sundholm, 'The mechanism of transpassive dissolution of $\mathrm{Ni}-\mathrm{Cr}$ alloys in sulphate solutions' Electrochim. Acta, 45, 2791 (2000).

11. L. J. Oblonsky and M. P. Ryan, 'In Situ X-Ray Absorption Near-Edge Structure Study of the Active and Transpassive Dissolution of Passive Films on $\mathrm{Ni}$ and Ni-Cr Alloys in $0.1 \mathrm{M} \mathrm{H}_{2} \mathrm{SO}_{4}$ ' J. Electrochem. Soc., 148, B405 (2001).

12. A. C. Lloyd, J. J. Noël, S. McIntyre, and D. W. Shoesmith, ' $\mathrm{Cr}$, Mo and $\mathrm{W}$ alloying additions in $\mathrm{Ni}$ and their effect on passivity' Electrochim. Acta, 49, 3015 (2004)

13. R. S. Lillard, M. P. Jurinski, and J. R. Scully, 'Crevice corrosion of alloy 625 in chlorinated ASTM artificial ocean water' Corrosion, 50, 251 (1994).

14. M. Bojinov and T. Tzvetkoff, 'The Influence of Solution Anion on the Mechanism of Transpassive Dissolution of Ferrous- and Nickel-Based Alloys' J. Phys. Chem. B, 107, 5101 (2003).

15. C. R. Clayton and I. Olefjord, in: P. Marcus ad J. Oudar (Ed.), Corrosion Mechanisms in Theory and Practice, Marcel Dekker, Inc. New York, 1995, Ch. 6.

16. A. J. Sedriks, Corrosion of Stainless Steels, Wiley, New York, 1979

17. A. C. Lloyd, D. W. Shoesmith, N. S. McIntyre, and J. J. Noël, 'Effects of Temperature and Potential on the Passive Corrosion Properties of Alloys C22 and C276' J. Electrochem. Soc., 150, B120 (2003).

18. H. Huang, 'Effect of chemical composition on the corrosion behavior of Ni-Cr-Mo dental casting alloys' J. Biomed. Mater. Res., 60, 458 (2002).

19. N. E. Hakiki, S. Boudin, B. Rondot, and M. Da Cunha Belo, 'The electronic structure of passive films formed on stainless steels' Corros. Sci., 37, 1809 (1995).

20. H. Tsuchiya, S. Fujimoto, O. Chihara, and T. Shibata, 'Semiconductive behavior of passive films formed on pure $\mathrm{Cr}$ and $\mathrm{Fe}-\mathrm{Cr}$ alloys in sulfuric acid solution' Electrochim. Acta, 47, 4357 (2002).

21. K. S. Raja, S. A. Namjoshi, and M. Misra, 'Improved corrosion resistance of $\mathrm{Ni}-22 \mathrm{Cr}-13 \mathrm{Mo}-4 \mathrm{~W}$ Alloy by surface nanocrystallization' Mater. Lett., 59, 570 (2005).

22. D. D. Macdonald, A. Sun, N. Priyantha, and P. Jayaweera, 'An electrochemical impedance study of Alloy-22 in $\mathrm{NaCl}$ brine at elevated temperature: II. Reaction mechanism analysis' J. Electroanal. Chem., 572, 421 (2004).

23. D. D. Macdonald, 'Passivity-the key to our metals-based civilization' Pure Appl. Chem., 71, 951 (1999).

24. C. R. Clayton and Y. C. Lu, 'A Bipolar Model of the Passivity of Stainless Steel: The Role of Mo Addition' $J$. Electrochem. Soc., 133, 2465 (1986).

25. M. Sakashita and N. Sato, 'The effect of molybdate anion on the ion-selectivity of hydrous ferric oxide films in chloride solutions' Corros. Sci., 17, 473 (1977).

26. K. Hashimoto, K. Asami, and K. Teramoto, 'An X-ray photo-electron spectroscopic study on the role of molybdenum in increasing the corrosion resistance of ferritic stainless steels in HC1' Corros. Sci., 19, 3 (1970).

27. H. Ogawa, H. Omata, I. Itoh, and H. Okada, 'Auger electron spectroscopic and electrochemical analysis of the effect of alloying elements on the passivation behavior of stainless steels' Corrosion, 34, 53 (1978).

28. M. Urquidi and D. D. Macdonald, 'Solute-Vacancy Interaction Model and the Effect of Minor Alloying Elements on the Initiation of Pitting Corrosion' $J$. Electrochem. Soc., 132, 555 (1985). 